Frontiers in Chemical Sciences (FCS)

Vol. 1, No. 2 (2020), pp. 1-8

\title{
Physicochemical Analysis of Different Brands of Chocolates and Their Comparative Studies \\ Mussarat Jabeen ${ }^{*}$, Marryam Imran', Ayesha Nawab ${ }^{1}$, Ayesha Ihsan ${ }^{1}$, Amna Ajmal $^{1}$, Sadia Mubeen', Sajida Parveen', Wania Adan', Ansa Madeeha Zafar¹, Noreen Aslam ${ }^{1}$ \\ ${ }^{1}$ Department of Chemistry, Government Sadiq College, The Women University \\ Bahawalpur, 63100 Pakistan \\ *dr.mussaratjabeen@gmail.com
}

\begin{abstract}
:
There is no metaphysics on earth like chocolate." Chocolate is a blessing which contain almost all nutrients necessary for the growth of human health. In this study, composition of different branded chocolates available in Pakistan including Dairy milk, Chocolate chip, Toblerone (black), Toblerone (sweet), Nutella, Smarties, Now, Sonnet, Novella and Snickers were qualitatively analyzed in triplicate. We successfully study proteins, fats, carbohydrates, sugar, alcohol, caffeine, calcium, magnesium, zinc, iron and nickel in different branded chocolates. From the results it is confirmed that $\mathrm{pH}$ of all chocolates are 6-9 depend on the concentration of cocoa which is same as reported in literature. All the chocolates contain high amount of fats, sugar and carbohydrates. Protein is present in excess amount in Chocolate chips and Snickers while Smarties, Sonnet and Novella contain small amount of protein but absent in rest of chocolate samples. None of the chocolate sample contain traces of alcohol. All chocolates contain calcium except Nutella, Now and Toblerone (black) while magnesium is only present in Smarties. All chocolates contain nickel except Sonnet and Now, zinc is absent in Sonnet, Now, Smarties and Nutella whileiron is only present in Dairy milk and chocolate chips. Some samples like Dairy milk, Chocolate chip, Toblerone (black), Snickers and Toblerone (sweet) contain traces of caffeine which act as stimulant and reduced liver damage. From the given results it is also confirmed that chocolates contain important ingredients which are helpful for proper body functioning.
\end{abstract}

Keywords: $\quad$ Chocolates, Dairy Milk, Calcium, Cocoa, Magnesium

\section{Introduction}

"The cheapest therapy which doesn't need any appointment is chocolate" (Parker, Parker, \& Brotchie, 2006). Likewise, chocolate has traditionally been associated with magical, medicinal and mythical properties. Chocolate melting in a person's mouth can cause a more intense and longer-lasting "buzz" than kissing. This can be illustrated with the statistics that the highest chocolate consumption is in Switzerland with 22 pounds per person each year (Seligson, Krummel, \& Apgar, 1994). Similarly, each person in Austria, Ireland, Germany and Norway consume 20.13 pounds, 19.47 pounds, 
18.04 pounds and 17.93 pounds, chocolate per year, respectively (Afoakwa, 2016). Worldwide, Asia contributes $17 \%$ of the total cocoa production annually and West Africa alone accounted for $71 \%$ of global cocoa supply. The seven largest cocoa producing countries are Ivory Coast, Ghana, Indonesia, Nigeria, Cameroon, Brazil and Ecuador (Beg, Ahmad, Jan, \& Bashir, 2017; Yanus et al., 2014).

The cocoa seeds from the fruit of "Theobroma cacao" tree (called it gift of ALLAH) are dried and fermented to make chocolate. Cocoa seeds in chocolate have fats $(18 \%)$, proteins $(34 \%)$, carbohydrates $(17 \%)$, fibers $(14 \%)$, minerals like sodium $(24 \mathrm{mg} / 100 \mathrm{~g})$, potassium $(559 \mathrm{mg} / 100 \mathrm{~g})$, calcium, magnesium $(252 \mathrm{mg} / 100 \mathrm{~g})$, iron $(10.9 \mathrm{mg} / 100 \mathrm{~g})$, zinc $(3.5 \mathrm{mg} / 100 \mathrm{~g})$, selenium $(0.1 \mathrm{mg} / 100 \mathrm{~g})$, poly-phenols, anti-oxidants (up to $12 \%$ ), caffeine $(20 \mathrm{mg} / 100 \mathrm{~g}$ ) and theobromine (Afoakwa, Quao, Takrama, Budu, \& Saalia, 2013; Bertazzo, Comai, Mangiarini, \& Chen, 2013; Chire-Fajardo, Arrunategui, Orihuela-Rivera, \& Ureña, 2017; Cinquanta et al., 2016; D. L. Katz, K. Doughty, \& A. Ali, 2011; McShea, Leissle, \& Smith, 2009). Interestingly, the cacao bean naturally contains almost 300 different flavors and 400 separate aromas. It takes approximately 400-600 cacao beans to make one pound of chocolate (Voora, Bermúdez, \& Larrea, 2019). Chocolates contain 35-90\% cocoa, 6-8\% fats and $3 \%$ water.Chocolate contains 300-500 known chemicals that react with human brain and alter their mood(Asmaro \& Liotti, 2014; Macht \& Dettmer, 2006). Every content in chocolate and its products contain high energy over $3000 \mathrm{kcal} / \mathrm{kg}$. Chocolate instantly melts in mouth and have soft, velvety, creamy, quality(Tan \& Kerr, 2017)and its physical, chemical, microbiological and sensory characteristics change fulfilling the respective demands of its customers (Della Lucia et al., 2015; Gatade, Ranveer, \& Sahoo, 2009). Chocolate desires are often periodic and oscillate with hormonal changes just before and during the Premenstrual, which settles the assumed gender-specific nature of chocolate cravings (Bruinsma \& Taren, 1999; Hallam, Boswell, DeVito, \& Kober, 2016; Osman \& Sobal, 2006; Rozin, Levine, \& Stoess, 1991; D. Zellner, Garriga-Trillo, Centeno, \& Wadsworth, 2004; D. A. Zellner, Garriga-Trillo, Rohm, Centeno, \& Parker, 1999).

Besides fats, proteins and carbohydrates, chocolate contains a large amount of minerals like iron, calcium, magnesium, zinc, selenium, potassium, sodium, vitamins like vitamin A, K, D, E, B12, B6, niacin, thiamin, folate that can cause beneficial effects on human health (Latif, 2013; Naveed, Hameed, Sharif, Ghafoor, \& Qamar, 2015; Visioli et al., 2009). Corresponding to this, calcium, magnesium, copper, sodium and potassium in chocolates are needed for vascular function (Corti, Flammer, Hollenberg, \& Lüscher, 2009; Kerimi \& Williamson, 2015). Iron deficiency is regarded as most important nutritional problem in the world which could be fulfilled with chocolate(D. L. Katz et al., 2011). Brian Buijsse and Zubaida Faridi revealed that Chocolate can improve endothelial function and reduce blood pressure (Buijsse, Feskens, Kok, \& Kromhout, 2006; Faridi, Njike, Dutta, Ali, \& Katz, 2008). Lower esophageal sphincter pressure has been found to be reduced by chocolates (Wright \& Castell, 1975). But eating too much chocolates can cause obesity, heartburn, prostate cancer due to the presence of flavonoids and increase in blood pressure (D. Katz, K. Doughty, \& A. Ali, 2011).

Keeping in view the above facts, due to the overwhelming demand and immensely increasing love of people for chocolates, we decided to conduct physicochemical analysis of different varieties of chocolates commonly available in markets of Pakistan to find out different constituents present in chocolate products. Moreover, a comparison between different varieties of chocolates is also given. 


\section{Material and methods}

\section{Study Area}

Ten chocolate samples, including Dairy milk, Chocolate chip, Toblerone (black), Toblerone (sweet), Nutella,Smarties, Now, Sonnet, Novella, and Snickers were collected from local market of Bahawalpur City and brought in Analytical Chemistry Laboratory, Department of Chemistry, Government Sadiq College Women University Bahawalpur. All the tests were performed in triplicate.

\section{Test for calcium}

$0.5 \mathrm{~g}$ chocolate was added to dilute ammonia solution to make the solution basic. Then ammonium oxalate solution added dropwise to the basic solution of chocolate. White precipitates confirm the calcium in sample. Calcium was also determined by flame test. Brick red color of flame indicates the presence of calcium.

\section{Test for reducing sugar}

$0.5 \mathrm{~g}$ of chocolate was added to $2 \mathrm{~mL}$ of a mixture of Fehling's A and Fehling's Bsolutions in a test tube and heated in water bath for 10 minutes. Brown colored precipitates indicated the presence of reducing sugar.

\section{Test for glucose}

$0.5 \mathrm{~g}$ chocolate of different brands were taken in the test tubes and $2 \mathrm{~mL}$ of Benedict's solution was added. The test tube was heated for few minutes. Formation of red color confirmed the presence of glucose.

\section{Test for alcohol}

$0.5 \mathrm{~g}$ sample was heated in a water bath for 30 minutes with $1 \mathrm{~mL}$ iodine solution, $1 \mathrm{~mL}$ potassium iodide solution and $1 \mathrm{~mL}$ sodium hydroxide solution. Yellow colored precipitates indicated the presence of alcohol.

\section{Test for caffeine}

$5 \mathrm{~g}$ chocolate was mixed with $2.0 \mathrm{~g}$ sodium carbonate solution. Magnesium sulphate was added to the extracted organic layer to remove water. Filter and evaporate the solution leaving few precipitates. After the addition of potassium chromate and 2-3 drops of concentrated $\mathrm{HCl}$ to the resulting precipitates, mixture was heated to evaporate all solvent. After the addition of $2 \mathrm{M}$ ammonium hydroxide solution, appearance of purple color indicates presence of caffeine.

\section{Test for Iron}

A mixture of ammonium chloride and ammonium hydroxide was added to each sample of chocolate. Presence of brown colored precipitates confirm the presence of iron.

\section{Test for nickel}

A mixture of ammonium chloride and ammonium hydroxide was added to each sample of chocolate. Then Na2S solution was added dropwise in each test tube. Presence of black colored precipitates confirm the nickel in sample. 


\section{Test for magnesium}

Chocolate sample was added to a mixture of ammonium chloride, ammonium hydroxide and sodium dihydrogen phosphate. White colored precipitates indicate presence of magnesium in sample.

\section{Test for fats}

Take a small sample of each chocolate on filter paper. Fold and unfold filter paper to crush the sample over a flame. Appearance of translucent spot around the sample which became larger on heating was observed.

\section{Test for Proteins}

$0.5 \mathrm{~g}$ of each sample of chocolate was added to sodium hydroxide solution. 1-2 drops of copper sulphate solution were added to the mixture, violet color indicating presence of proteins.

\section{Test for carbohydras}

$0.5 \mathrm{~g}$ of each sample of chocolate taken in different test tubes. $1 \mathrm{~mL}$ of water was added to make a mixture, then few drops of sulphuric acid along inner edges of test tubes followed by molisch's reagent ( $\alpha$-naphthol in alcohol) were added. A very beautiful purple ring is formed on the top indicates presence of carbohydras.

\section{2. $\mathrm{pH}$ determination}

$\mathrm{pH}$ of chocolates was measured by using $\mathrm{pH}$ paper.

\section{Test for zinc}

$0.5 \mathrm{~g}$ sample was added to $5 \mathrm{M}$ solution of $\mathrm{HCl}$ to make solution acidic. Few drops of 0.5 $\mathrm{M}$ potassium ferro-cyanide solution were added in acidic solution. whitish grey precipitates confirm the presence of zinc.

\section{Results and Discussion}

According to the literature, chocolates are beneficial and contain proteins, fats, carbohydrates minerals which are necessary for performing different body functions. Composition of chocolate is different that can be vary from brand to brand. To evaluate their composition, we use 10 different brands of chocolates were used for qualitative analysis. The samples were collected from local market of Bahawalpur, Pakistan and brought to Chemistry Department of Government Sadiq College Women University Bahawalpur.Calcium, magnesium, zinc, sugar, carbohydrates, proteins, fats, alcohol, caffeine, $\mathrm{pH}$ and iron were qualitatively analyzed. The data is summarized in Table 1 and Table 2. 
Table 1: Estimation of $\mathrm{pH}$, fats, carbohydrates, sugar, protein, and alcohol in different brands of Chocolates

\begin{tabular}{|c|c|c|c|c|c|c|c|}
\hline $\begin{array}{l}\text { Sr. } \\
\text { No. }\end{array}$ & Sample Name & $\mathrm{pH}$ & Fats & Proteins & Sugar & Carbohydrates & Alcohol \\
\hline 1 & Dairy Milk & 6 & + & - & + & + & - \\
\hline 2 & Toblerone (Black) & 9 & + & - & - & - & - \\
\hline 3 & Toblerone (Sweet) & 7 & ++ & - & + & + & - \\
\hline 4 & Chocolate Chips & 6 & + & ++ & + & + & - \\
\hline 5 & Nutella & 6 & + & - & + & + & - \\
\hline 6 & Smarties & 6 & + & + & + & + & - \\
\hline 7 & Snickers & 7 & ++ & ++ & + & + & - \\
\hline 8 & Now & 6 & ++ & - & + & + & - \\
\hline 9 & Sonnet & 6 & ++ & + & + & + & - \\
\hline 10 & Novella & 7 & + & + & + & + & - \\
\hline
\end{tabular}

Table 2: Estimation of calcium, magnesium, iron, caffeine, zinc and nickel in different brands of Chocolates

\begin{tabular}{llllllll}
\hline $\begin{array}{l}\text { Sr. } \\
\text { No. }\end{array}$ & Sample Name & Calcium & Magnesium & Nickel & Zinc & Iron & Caffeine \\
\hline 1 & Dairy Milk & + & - & + & + & + & + \\
\hline 2 & $\begin{array}{l}\text { Toblerone } \\
\text { (Black) }\end{array}$ & - & - & + & + & - & + \\
\hline 3 & $\begin{array}{l}\text { Toblerone } \\
\text { (Sweet) }\end{array}$ & + & - & + & + & - & + \\
& $\begin{array}{l}\text { Chocolate } \\
\text { Chips }\end{array}$ & + & - & + & + & + & + \\
\hline 4 & Nutella & - & - & + & - & - & - \\
\hline 5 & Smarties & + & + & + & - & - & - \\
\hline 6 & Snickers & + & - & + & + & - & + \\
\hline 8 & Now & - & - & + & - & - & - \\
\hline 9 & Sonnet & + & + & - & + & - & - \\
\hline 10 & Novella & + & + & + & - & - \\
\hline+
\end{tabular}

$+=$ present; $-=$ absent; $++=$ present in excess

As the optimum $\mathrm{pH}$ of chocolate must be 6.3 to 6.7 or roughly $7, \mathrm{pH}$ of chocolates was checked by $\mathrm{pH}$ paper. $\mathrm{pH}$ meters are usually much more precise and accurate than test strips but due to unavailability of $\mathrm{pH}$ meter we use $\mathrm{pH}$ paper for $\mathrm{pH}$ detection. $\mathrm{pH}$ of all brands ranges from 6-7, except Toblerone (Black) which had $9 \mathrm{pH}$. Fats in chocolates were estimated by placing desired chocolate on filter paper and examine after folding. Fats may cause obesity, all chocolates contain fats but Toblerone (sweet), Snickers, Now and Sonnet contain excess amount of fats. Proteins is important building blocks of bones, muscles, cartilage, skin and blood, can build and repair tissues. Protein in chocolates was confirmed by adding sodium hydroxide solution and 1-2 drops of copper sulphate solution resulting appearance of violet color. Novella, Sonnet and Smarties contain small amount of proteins while chocolate chips and Snickers contain protein in excess amount. Sugars provide burst of energy and an instant mood boost but excess can cause weight gain.Sugar was detected by heating sample with Fehling A and Fehling B solution resulting brown colored precipitates, all chocolates contain sugar except Toblerone (black).When sample is heated with iodine solution, potassium iodide and sodium 
hydroxide solution yellow colored precipitates indicate presence of alcohol. None of the testing chocolate give positive test for alcohols. Carbohydras give energy to our body and are necessary for proper body functioning. Carbohydrate was confirmed by Molisch's reagent and a very beautiful purple ring formed on the top, all chocolates give positive test except Toblerone (black).

Chocolates contain minerals like calcium, magnesium, zinc, iron, selenium, etc., that are necessary for human health. Calcium provide bone strength, necessary for maintaining healthy communication between the brain and other parts of the body. All the test samples contain calcium except Toblerone (black), Nutella and Now. Although, dietary calcium is generally safe, excessive calcium does not provide extra bone protection and causes problems especially harness of bones. Magnesium is important for muscle and nerve function, regulating blood pressure, and supporting the immune system. Among, all the tested samples only Smarties contain magnesium. Nickel is heavy metal and can be dangerous for human health but nickel is added to chocolates for increasing their melting point and for preventing it from melting at normal temperature. According to WHO nickel is likely safe for adults in amounts up to $1 \mathrm{mg}$ daily. Nickel was estimated by drop wise addition of sodium sulfide after the addition of ammonium chloride and ammonium hydroxide in chocolate, resulting black colored precipitates. All the test chocolates give black colored precipitates.

Caffeine may reduce the liver damage, increase energy level, protects from Alzheimer's disease, fat burner and reduced depression. Caffeine also has many side effects like anxiety, drowsiness, dehydration and confusion are common. All the test samples except Nutella, Smarties, Now, sonnet and Novella give a positive test for caffeine. Zinc has capacity to reduce the age-related diseases, among all the tested sample only Dairy milk and Chocolate chipscontain iron while rest give negative test. Zinc is also an important nutrient and is present in all samples except Nutella, Smarties, Now and Sonnet.

\section{Conclusions}

The present study revealed that most of the chocolates have $\mathrm{pH}$ 6-7 slightly acidic due to the presence of lactic acid while Toblerone (black) have pH 9 slightly basic which may due to the presence of high amount of cocoa. Similarly, all chocolates except Toblerone (black) contain carbohydrates, sugars and glucose due to this, the taste of Toblerone (black) is bitter. All the chocolates contain fats in the form of cocoa butter used for the preparation of chocolates. As proteins are necessary for our development, some tested chocolates contain excess amount of proteins like Chocolate chips and Snickers while Smarties, Sonnet and Novella contain small amount of proteins. Alcohol cause critical effects on body and fortunately, none of the tested chocolate contain alcohol. Many of the tested chocolates contain minerals like calcium, magnesium, zinc and iron which increase their importance in daily life as a food. Nickel can cause respiratory problems, itching, blisters and rashes. It also decreases the melting of chocolates at room temperature. Almost all the tested samples contain nickel. Caffeine is also known as mood changer but excess can damage nervous system. Among all the tested samples, Nutella, Smarties, Now, Sonnet and Novella does not contain caffeine. From this study, it is concluded that chocolates are beneficial for humans and can recover the deficiency of many minerals but their excess use can be dangerous for human health. 


\section{References}

Afoakwa, E. O. (2016). World cocoa production, processing and chocolate consumption pattern Chocolate Science and Technology (2nd ed., pp. 17-48): Wiley.

Afoakwa, E. O., Quao, J., Takrama, J., Budu, A. S., \& Saalia, F. K. (2013). Chemical composition and physical quality characteristics of Ghanaian cocoa beans as affected by pulp pre-conditioning and fermentation. International Journal of Food Science \& Technology, 50(6), 1097-1105.

Asmaro, D., \& Liotti, M. (2014). High-Caloric and Chocolate Stimuli Processing in Healthy Humans: An Integration of Functional Imaging and Electrophysiological Findings. Nutrients, 6(1), 319-341.

Beg, M. S., Ahmad, S., Jan, K., \& Bashir, K. (2017). Status, supply chain and processing of cocoa - A review. Trends Food Sci. Technol., 66, 108-116.

Bertazzo, A., Comai, S., Mangiarini, F., \& Chen, S. (2013). Composition of Cacao Beans. In V. Preedy, S. Zibadi \& R. Watson (Eds.), Chocolate in Health and Nutrition (pp. 105-117): Springer.

Bruinsma, K., \& Taren, D. L. (1999). Chocolate: food or drug. Journal of the American Dietetic Association, 99(10), 1249-1256.

Buijsse, B., Feskens, E. J., Kok, F. J., \& Kromhout, D. (2006). Cocoa intake, blood pressure, and cardiovascular mortality: the Zutphen Elderly Study. Archives of Internal Medicine, 166(4), 411-417.

Chire-Fajardo, G., Arrunategui, R., Orihuela-Rivera, C., \& Ureña, M. (2017). Assessment of physical and physicochemical quality of main chocolates traded in Peru. Acta Agronomica, 66(4), 164-171.

Cinquanta, L., Di Cesare, C., Manoni, R., Piano, A., Roberti, P., \& Salvatori, G. (2016). Mineral essential elements for nutrition in different chocolate products. international research on food science and nutrition, 67(7), 773-778.

Corti, R., Flammer, A. J., Hollenberg, N. K., \& Lüscher, T. F. (2009). Cocoa and Cardiovascular Health. Circulation, 119(10), 1433-1441.

Della Lucia, F., Carmo, J., Morais, C., Nunes, C., Pinheiro, A., Ferreira, E., et al. (2015). Physicochemical and sensory quality of several commercial Brazilian chocolate milk beverages. International Journal of Dairy Technology, 1-8.

Faridi, Z., Njike, V. Y., Dutta, S., Ali, A., \& Katz, D. L. (2008). Acute dark chocolate and cocoa ingestion and endothelial function: a randomized controlled crossover trial. American Journal of Clinical Nutrition, 88(1), 58-63.

Gatade, A., Ranveer, D. R., \& Sahoo, A. (2009). Physico-Chemical and Sensorial Characteristics of Chocolate Prepared from Soymilk. Advance Journal of Food Science and Technology, 1, 1-5.

Hallam, J., Boswell, R. G., DeVito, E. E., \& Kober, H. (2016). Gender-related Differences in Food Craving and Obesity. Yale Journal of Biology and Medicine, 89(2), 161-173.

Katz, D., Doughty, K., \& Ali, A. (2011). Cocoa and Chocolate in Human Health and Disease. Antioxidant, 15, 2779-2811.

Katz, D. L., Doughty, K., \& Ali, A. (2011). Cocoa and chocolate in human health and disease. Antioxidant, 15(10), 2779-2811. 
Kerimi, A., \& Williamson, G. (2015). The cardiovascular benefits of dark chocolate. Current Vascular Pharmacology, 71, 11-15.

Latif, R. (2013). Chocolate/cocoa and human health: A review. Netherlands Journal of Medicine, 71, 63-68.

Macht, M., \& Dettmer, D. (2006). Everyday mood and emotions after eating a chocolate bar or an apple. Appetite, 46(3), 332-336.

McShea, A., Leissle, K., \& Smith, M. A. (2009). The essence of chocolate: a rich, dark, and well-kept secret. Nutrition, 25(11-12), 1104-1105.

Naveed, D. S., Hameed, A., Sharif, N., Ghafoor, S., \& Qamar, F. (2015). Chocolate Consumption in Children and Adults. 7.

Osman, J. L., \& Sobal, J. (2006). Chocolate cravings in American and Spanish individuals: biological and cultural influences. Appetite, 47(3), 290-301.

Parker, G., Parker, I., \& Brotchie, H. (2006). Mood state effects of chocolate. Journal of Affective Disorders, 92(2-3), 149-159.

Rozin, P., Levine, E., \& Stoess, C. (1991). Chocolate craving and liking. Appetite, 17(3), 199-212.

Seligson, F. H., Krummel, D. A., \& Apgar, J. L. (1994). Patterns of chocolate consumption. American Journal of Clinical Nutrition, 60(6 Suppl), 1060s1064 s.

Tan, J., \& Kerr, W. (2017). Determination of chocolate melting properties by capacitance based thermal analysis (CTA). Journal of Food Measurement and Characterization, 12 .

Visioli, F., Bernaert, H., Corti, R., Ferri, C., Heptinstall, S., Molinari, E., et al. (2009). Chocolate, Lifestyle, and Health. Critical Reviews in Food Science and Nutrition, 49, 299-312.

Voora, V., Bermúdez, S., \& Larrea, C. (2019). Global Market Report: Cocoa. Canada: IISD.

Wright, L. E., \& Castell, D. O. (1975). The adverse effect of chocolate on lower esophageal sphincter pressure. American Journal of Digestive Diseases, 20(8), 703-707.

Yanus, R. L., Sela, H., Borojovich, E. J., Zakon, Y., Saphier, M., Nikolski, A., et al. (2014). Trace elements in cocoa solids and chocolate: an ICPMS study. Talanta, $119,1-4$.

Zellner, D., Garriga-Trillo, A., Centeno, S., \& Wadsworth, E. (2004). Chocolate craving and the menstrual cycle. Appetite, 42, 119-121.

Zellner, D. A., Garriga-Trillo, A., Rohm, E., Centeno, S., \& Parker, S. (1999). Food liking and craving: A cross-cultural approach. Appetite, 33(1), 61-70. 